\title{
sone \\ Comparison of Biodegradation Performance of Marine Sponge Symbiont Bacteria Consortium against Anthracene and Pyrene
}

\author{
Ismail Marzuki 1 ${ }^{*}$, Ruzkiah Asaf 2, Mudian Paena ${ }^{2}$, Admi Athirah ${ }^{2}$, Khairun Nisaa ${ }^{3}$, Rasheed Ahmad ${ }^{4}$, Mudya- \\ wati Kamaruddin 5
}

1 Department of Chemical Engineering, Fajar University, Makassar - South Sulawesi 90231, Indonesia; ismailmz@unifa.ac.id; ismailmz3773@gmail.com

2 Research Center for Brackish Aquaculture Fisheries and Extension Fisheries, Maros District - South Sulawesi 90512, Indonesia; qiaasaf@gmail.com; mudianpaena@yahoo.co.id; m.athirah@gmail.com

3 Fishery Faculty, Cokroaminoto University of Makassar, Makassar - South Sulawesi 90245, Indonesia; nisauicha27@gmail.com

4 Departement of Chemistry, Airlangga University, Mulyorejo-Surabaya, East Java,60115, Indonesi; rasheed.ahmad@fst.unair.ac.id

5. Postgraduate Program, Department of Medical Laboratory Science, Muhammadiyah Semarang University. Semarang Central Java, 50273, Indonesia; mudyawati@unimus.ac.id;

* Correspondence: ismailmz3773@gmail.com (I.M.); ismailmz@unifa.ac.id (I.M.)

\begin{abstract}
Every petroleum processing industry produces sewage sludge containing several types of polycyclic aromatic hydrocarbon (PAHs) components. The degradation of PAH components by physical, biological and chemical methods is not efficient. The use of marine sponge symbiont bacteria is considered an alternative method in the degradation and reduction of PAHs compared to the previous method. This study aims to explore the potential and performance of a consortium of sponge symbiont bacteria in degrading anthracene and pyrene. There are three types of bacteria (Bacillus pumilus strain GLB197, Pseudomonas stutzeri strain SLG510A3-8, Acinetobacter calcoaceticus strain SLCDA 976) were mixed to form a consortium. The interaction between the bacterial consortium suspension and PAH components was measured at 5-day intervals for 25 days. The biodegradation performance of bacteria on PAHs samples was determined based on five biodegradation parameters. The analysis results showed a decrease in the concentration of anthracene $(21.89 \%)$ and pyrene $(7.71 \%)$, equivalent to a ratio of $3: 1$. The data was followed by a decrease in the abundance of anthracene $(60.30 \%)$ and pyrene $(27.52 \%)$, an equivalent ratio of $2: 1$. The level of degradation of the pyrene component is lower than that of the anthracene component, presumably due to the higher toxicity of pyrene and the more stable molecular structure, making it difficult for bacterial cells to destroy it. The biodegradation products are organic compounds of alcohol, aldehyde, carboxylic acids and a small proportion of aromatic hydrocarbon components.
\end{abstract}

Keywords: performance; biodegradation; bacterial consortium; marine sponge; PAHs

\section{Introduction}

Anthracene and pyrene are a class of hydrocarbon aromatic polycyclic compounds. The molecular structure is stable by the ring's resonance ability of pi $(\pi)$ bonds. The two types of PAHs were first isolated from coal tar, volatile compounds formed from incomplete combustion of organic compounds in protein-rich foods [1]. The primary sources of anthracene and pyrene are coal tar, condensation compounds of natural gas and petroleum distillation, and coal tar. Which is found in plants such as tobacco tar, can also be found in certain areas animals like deer and termites [2]. Anthracene is a moderately toxic and carcinogenic PAHs compound. Pyrene is a highly toxic PAHs group, carcinogenic 
and genotoxic or mutagenic [3-5]. Anthracene is widely used as an antiseptic and insecticide, while pyrene increases the octane number of fossil fuels [6,7]. The use of anthracene and pyrene in today's life is quite extensive so that they have the potential as components of pollutants in the air, soil and water $[8,9]$. The character of PAHs, anthracene and pyrene, and other PAHs is difficult to decompose and accumulate in a material, including living organisms. Suppose these PAHs are released in the environment for a long time, followed by changes in weather, rain, fluctuating air temperatures. It is predicted that they can disrupt the ecological balance, change biogeochemical cycles, and even cause severe problems for the ecosystem, especially for the environment. -abiotic, biotic and environmental interactions [10 This condition can cause a negative chain effect because the PAHs component dissolves in water bodies, forming a flow from the high to the low, finally empties into the sea [11].

The sea is a giant container that can accommodate all the materials that go into it. There are thousands of types of biota interacting with each other in the sea, including the reversible relationship between all abiotic components and biotic components, both those already available in the sea and new materials that enter the marine environment $[12,13]$. This condition results in new adaptations in the sea, resulting in changes in new life patterns of marine ecosystems [14,15]. If the discharge of PAHs into the sea is not controlled, fish and other biota are potentially exposed to the carcinogenic components of anthracene and pyrene [16, 17]. The fish are caught by fishermen and eventually consumed by the community [18]. This process eventually forms the cycle and flow of the food chain; in the long run, it causes environmental quality to decline and human health levels to be lower [19].

The formation of interaction patterns and models, the order of a new ecosystem balance in the sea between abiotic and biotic components as a form of adaptation to the above conditions, causes many biotas to experience pressure regulating their lives. However, there is also biota that survives more with the new pattern [20,21]. One of the biotas that survive with the new pattern is the sea sponge because it has a strong ability to adapt to changes in habitat [22]. There are four forms of adaptation of marine sponges: first, the ability to form a mutualism symbiosis with bacteria so that sponges can survive in habitats contaminated with waste types of PAHs and heavy metals [23]. Second, the nutritional pattern of sponges is a filter feeder with a body structure that has oscula, enabling it to obtain and absorbs food that is needed and not needed, disposed of by spraying it out [24]. Third, sponges can produce mucus substances that act as enzymes, which can be spread on the surface of their bodies as camouflage against predatory threats [25-26]; Fourth, the ability of sponges to absorb carbon components and convert them into energy for activities, including being able to absorb heavy metals [27 - 30]. Some scientific data show this adaptability because sponges are one of the marine biotas with an old civilization level. The DNA structure of sponges is easy to respond to habitat changes [31].

In addition to having the ability to degrade carbon components, especially PAHs, Sponges also have bioindicator and biomonitoring functions as well as bio-adsorption of heavy metals. It is due to their ability to produce enzymes (metabolic components) that can absorb and neutralize the toxic nature of the waste [32-34]. Sponges also have the function of biodegradation of aliphatic and aromatic hydrocarbon components, presumably because of the role of symbiotic bacteria they have or because of the metabolic components produced $[35,36]$. The function of biodegradation of PAHs and bio-adsorption of heavy metals has earned the marine sponge the nickname of biota with dual functions and significant benefits in reducing pollutants and maintaining the quality of the marine environment $[37,38]$.

The facts mentioned above prompted us to carry out mapping and a series of continuous research. It explores the function of sponges reducing PAHs and heavy metal pollutants in the marine environment through screening of symbiont bacteria. So that data, collections, and even formulas of marine sponge symbiont bacteria can be compiled with biodegradation and bio-adsorption, arranged in the form of a mobile crystalline bacterial 
consortium so that it is quickly mobilized to the pollution site $[1,11,39]$. Characterization of sponges and symbiotic bacteria, including analysis of the biodegradation potential of PAHs, is essential [40]. The application and increase in the biodegradation rate of symbiont bacteria to hydrocarbon pollutants, especially PAHs, is seen as a necessity [41,42]

Several species of sponge symbiont bacteria can also carry out the bio-adsorption function of several types of heavy metals, namely: Mercury (Hg), Chromium (Cr), Arsenic $(\mathrm{As})$, Lead (Pb), Cadmium (Cd), Copper (Cu), Nickel (Ni), Zink (Zn) and Cobalt (Co) [4346]. The development of the function and performance of biodegradation of PAHs and bio-adsorption of heavy metals by sponge symbiont bacteria in the form of a consortium of potential bacteria can be carried out efficiently and effectively manage polluted environments to reduce global trend waste pollutants [47]. Another effort is to carry out extreme environmental engineering contaminated with various PAHs and heavy metals [48]. The role and function of sponge symbiont biomass and bacteria in improving the quality and quality of the marine environment is enormous. It is especially in improving the biodegradation performance of PAHs through the role of the bacterial consortium formulation so that real work is realized to preserve the environment while keeping the marine sponge population growing and developing. The other is the cultivation of marine sponges using the trans-plantation method [49-51].

\section{Results}

An essential point of concern, observation and analysis in research comparing the degradation of the consortium of marine sponge symbiont bacteria to the anthracene and pyrene components consists of two main parts. These include: first, the preparation of the marine sponge symbiont bacteria consortium, which begins with the characteristics of the sampling point, Morphology analysis, bacterial isolation, phenotypic and genotypic analysis of bacterial isolates, selection of potential biodegradation bacteria isolated from marine sponges. Second, biodegradation parameters, an abundance of a substrate, percentage of degraded components, types of total components and functional groups, which are biodegradation products of the bacterial consortium.

\subsection{Characteristics of seawater at the sampling location}

Characterization of seawater at the point of acquisition of sponge samples is intended to investigate whether there is a relationship between the habitat of the sponge, the presence of hazardous and toxic contaminants and the potential symbiosis of microorganisms (bacteria) in the biodegradation of hydrocarbon components. The sampling location for sea sponges is in the waters around Kodingareng Keke Island, the administrative area of Makassar Metro City, South Sulawesi. The island is one of the Maritime Tourism Areas developed by the Makassar City government and is included in the Spermonde Archipelago Cluster.

Table 1. Characteristics of seawater sampling points of sponges around Kodingareng Keke Island

\begin{tabular}{|c|c|c|c|c|c|c|c|c|}
\hline $\begin{array}{l}\text { Sample } \\
\text { code }\end{array}$ & Coordinate & $\begin{array}{l}\text { Salinity } \\
(\% \text { ) }\end{array}$ & $\begin{array}{c}\text { Tempera- } \\
\text { ture } \\
\left({ }^{\circ} \mathrm{C}\right)\end{array}$ & $\mathrm{pH}$ & $\begin{array}{c}\text { TDS } \\
(\mathrm{mg} / \mathrm{L})\end{array}$ & $\begin{array}{c}\text { DHL } \\
(\mathrm{ds} / \mathrm{m})\end{array}$ & $\begin{array}{l}\text { Depht dpl } \\
\quad(\mathrm{m})\end{array}$ & $\begin{array}{l}\text { Distance } \\
\text { from the } \\
\text { beach (m) }\end{array}$ \\
\hline Sp1 & $\begin{array}{r}\mathrm{S} 5^{\circ} 6^{\prime} 38,12376^{\prime \prime} \\
\text { E } 119^{\circ} 17^{\prime} 70,76544^{\prime \prime}\end{array}$ & 28,3 & 29,4 & 7,47 & 7,41 & 14,46 & $\pm 3,20$ & \pm 200 \\
\hline Sp2 & $\begin{array}{r}\mathrm{S} 5^{\circ} 6^{\prime} 11,62476^{\prime \prime} \\
\text { E } 119^{\circ} 17^{\prime} 60,06228^{\prime \prime}\end{array}$ & 28,1 & 30,9 & 7,69 & 7,21 & 14,20 & $\pm 3,74$ & \pm 250 \\
\hline Sp3 & $\begin{array}{r}\mathrm{S} 5^{\circ} 6^{\prime} 23,55372^{\prime \prime} \\
\mathrm{E} 190^{\circ} 20^{\prime} 27,62376^{\prime \prime}\end{array}$ & 27,3 & 30,3 & 7,70 & 7,50 & 12,87 & $\pm 4,25$ & \pm 370 \\
\hline
\end{tabular}

\subsection{Analisis morfologi sampel spons laut}




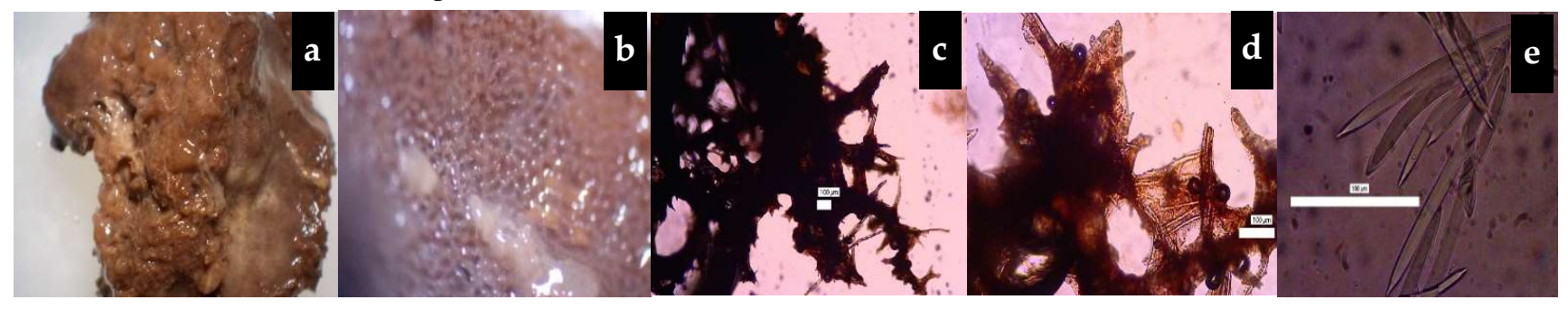

Figure 1. The morphology of the marine sponge Niphates sp. (Sp1). (a) Consistency: smooth, porous surface, covered by a muddylike mucus, inelastic and brittle body; (b) Surface: granular spongy surface; (c) Skeleton: skeleton of spicules with echinating spicules; (d) Skeletal tract, high fibre spicular tract skeleton; and (e) Spicules: oxeal megasclera appear slight (40x).

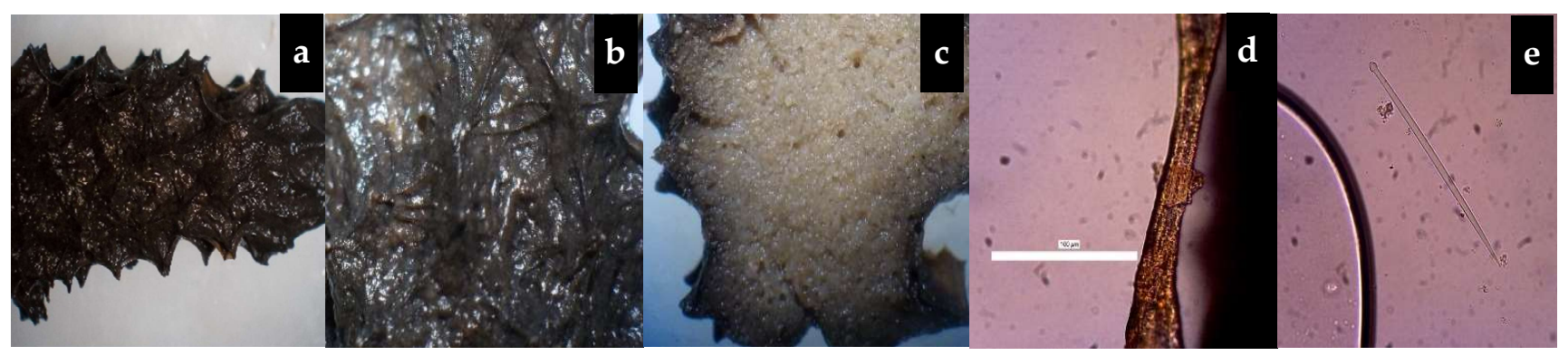

Figure 2. The morphology of the marine sponge Hyrtios erectus (Sp2). (a) Consistency: the surface of the body is smooth, dark in colour and covered by mucus substance, the ossicles are not identified, the characteristics of the sponge are fleshy, the body of the sponge is less elastic and looks brittle; (b) Surface: the surface looks like a pyramid-shaped ornament; (c) Choanosomes: body parts. Heavy fiber body sponge; (d) Skeleton: Fiber-character framework; and (e) Spicules, megacler sub stylostyle (10x magnification), no scleral microscopy.

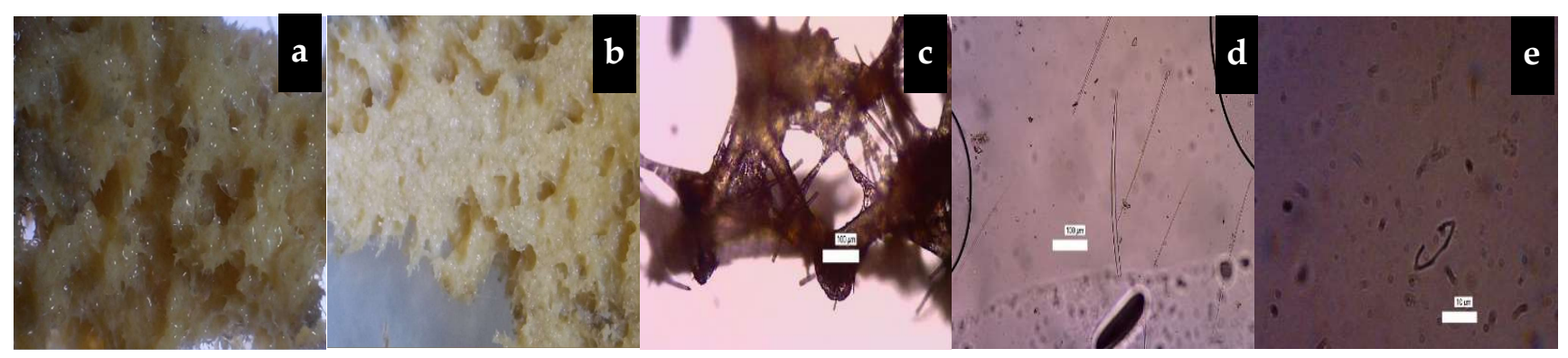


Figure 3. Morphology of the marine sponge Clathria (Thalysias) reinwardtii (Sp3). (a) Consistency: soft consistency, compressible spongy, slimy body surface but appear lighter; (b) Projection: sponge body brittle as it dries; (c) Choanosome: Anastoming reticulate choano-some skeleton; (d) Megasclere: megasclere appears elongated; and (e) Microsclera, Microsclera in the form of Chelae.

\subsection{Isolation and phenotypic characteristics of marine sponge symbiont bacteria}

Potential bacteria for biodegradation of PAHs can be obtained from marine sponges by isolation. Phenotypic characteristics characterized the isolates obtained to determine morphology, Gram group and the tendency of isolates' ability to several biochemical test reagents. This method is a preliminary test to predict marine sponge symbiont isolates' ability to biodegrade PAH components.

The results of the phenotypic characterization of 3 (three) bacterial isolates showed that these bacterial isolates had spores and were Gram-positive bacteria and generally reacted positively to 7 (seven) types of biochemical reagents that had been tested. Combining these three types of sponge symbiont bacterial isolates in the form of a bacterial consortium suspension was considered sufficient and fulfilled all the requirements needed to carry out the biodegradation process of PAH components [9,31]. Several conditions are needed so that bacteria can carry out the biodegradation reaction of hydrocarbon components as a substrate are to have enzymes capable of hydrolyzing amino acids as indicated by the indole test. In addition, it can also be able to carry out the fermentation reaction shown by the TSIA test, reducing nitrate to nitrile as shown by the nitrate test and breaking bonds. The urease test indicated carbon. A positive result of the citrate test showed that bacteria could reduce carbon, convert it into energy, and carry out the reaction of reducing carbohydrates to alcohol by the VP test and reducing carbohydrates to acid products by the Mr. test. The phenotypic analysis also gave clues that it could be concluded that the bacterial isolate coded Sp1, which was isolated from the sponge Niphates sp., belongs to the Bacillus group, Sp2 or sponge isolate Hyrtios erectus, is a bacterium from the Pseudomonas group. In contrast, the isolate coded Sp3 isolated from the sponge Clathria (Thalysias) reinwardtii is a bacterium belonging to the Acinetobacter group $[22,24,29]$.

Table 2. Phenotypic characteristics of marine sponge symbiont bacterial isolates

\begin{tabular}{|c|c|c|c|}
\hline \multirow[b]{2}{*}{ Parameters } & \multicolumn{3}{|c|}{ Marine sponge symbiont bacteria isolate } \\
\hline & Sp1 (Niphates sp.) & Sp2 (Hyrtios erectus) & $\begin{array}{c}\text { Sp3 (Clathria (Thalysias) } \\
\text { reinwardtii) }\end{array}$ \\
\hline Morphology & $\begin{array}{l}\text { jagged stem shape, cream col- } \\
\text { our, clustered distribution, en- } \\
\text { dospore is less clear }\end{array}$ & $\begin{array}{l}\text { jagged stem shape, brown col- } \\
\text { our, separate distribution with } \\
\text { endospores }\end{array}$ & $\begin{array}{l}\text { round shape, bluish-cream } \\
\text { colour, clustered distribu- } \\
\text { tion, endospores are less } \\
\text { clear }\end{array}$ \\
\hline Golongan Gram & $\begin{array}{l}\text { reaction (-) with safranin rea- } \\
\text { gent and (-) with } 1 \% \mathrm{KOH} \text { al- } \\
\text { kaline solvent, Basil gram (+) }\end{array}$ & $\begin{array}{l}\text { fixed colour with safranin rea- } \\
\text { gent and (-) with } 1 \% \mathrm{KOH} \text { alka- } \\
\text { line solvent, Basil gram (+) }\end{array}$ & $\begin{array}{l}\text { reaction (-) with safranin } \\
\text { and (-) with } 1 \% \mathrm{KOH} \text { alka- } \\
\text { line solvent, Basil gram (+) }\end{array}$ \\
\hline Indole test & - & - & + \\
\hline Triple Sugar Iron Agar (TSIA) & + & + & - \\
\hline Nitrate test & + & + & - \\
\hline Simmone Citrate test & - & + & + \\
\hline Methyl red $(\mathrm{Mr})$ test & - & + & + \\
\hline Voges-Proskauer (VP) test & + & - & + \\
\hline Urease test & + & + & + \\
\hline Provisional guess & Bacillus group & Pseudomonas group & Acinetobacter group \\
\hline
\end{tabular}

Note: - : not react; + : positive reaction

\subsection{Genotypic analysis of marine sponge symbiont bacteria}

$t$ is necessary to know the bacterial genotype of marine sponge symbionts to ascertain the types and strains of bacteria used to degrade PAHs components. Based on the 
data on the grouping of marine sponge symbiont bacteria (Table 2), the three types of isolates were given a new code following the suspected bacterial class, Sp1-Bc, Sp2-Ps and Sp3-Ac, respectively.

Table 3. Genotypic characteristics of marine sponge symbiont isolate that are potential as biodegradators of PAHs Anthracene and Pyrene components

\begin{tabular}{cccccl}
\hline $\begin{array}{c}\text { Bacterial } \\
\text { isolate }\end{array}$ & $\begin{array}{c}\text { Sequence } \\
\text { samples }\end{array}$ & $\begin{array}{c}\text { Range sequence } \\
\text { gen-Bank }\end{array}$ & $\begin{array}{c}\text { Identities } \\
\text { quality } \\
\mathbf{( \% )}\end{array}$ & $\begin{array}{c}\text { Gaps } \\
\mathbf{( \% )}\end{array}$ & Species type \\
\hline Sp1-Bc & $15-967$ & $710.748-711.700$ & $922 / 956$ & $6 / 956$ & Bacillus pumilus \\
& $(952)$ & $(952)$ & $(96,44)$ & $0,63)$ & $\begin{array}{l}\text { strain GLB197 } \\
\text { Sp2-Ps }\end{array}$ \\
& $14-975$ & $3.666 .632-3.667 .587$ & $890 / 974$ & $30 / 974$ & $\begin{array}{l}\text { Pseudomonas stut- } \\
\text { zeri strain }\end{array}$ \\
& $(961)$ & $(955)$ & $(91,14)$ & $(3,08)$ & SLG510A3-8 \\
Sp3-Ac & $9-961$ & $12-964$ & $951 / 954$ & $2 / 954$ & $\begin{array}{l}\text { Acinetobacter calco- } \\
\text { aceticus strain } \\
\end{array}$ \\
& $(952)$ & $(952)$ & $(99,69)$ & $(0,21)$ & SLCDA976 \\
\hline
\end{tabular}

\subsection{Biodegradation of PAHs. Components}

2.5.1 Parameters of PAHs biodegradation by marine sponge symbiont consortium bacteria

The physical interaction media of the bacterial consortium suspension against the PAHs contaminants changed during the biodegradation process. Several general parameters can be observed as indicators of the ongoing biodegradation process, including media turbidity, fermentation odor, $\mathrm{pH}$ changes, and gas bubbles' formation. These parameters are characteristic of fermentation that is played by bacteria or enzymes on a substrate containing protein, glucose, including materials containing hydrocarbon components. Biodegradation that takes place follows the pattern of enzymatic reactions. The enzyme components are thought to be produced by bacteria in response to their habitat conditions contaminated with hydrocarbon components. The production of mucus with enzyme characteristics is produced as an effort for bacteria to defend themselves to survive in PAH contaminated media. Therefore, observation of physical changes in the interaction media is oriented towards the performance of enzymatic reactions with the appearance of fermentation odor parameters and abundance of gas bubbles [29-31].

The relative turbidity of the media increased with increasing interaction time, indicating that there was an increase in the size and number of bacterial cells. The increase in temperature, the relative increase in acidity of the interactive media, the emergence of gas bubbles and the smell of fermentation are strong indications of a biodegradation process occurring in the media. These parameters are characteristic of the fermentation process, which is thought to be played by enzymes produced by marine sponge symbiont bacteria as a response and adaptation of bacteria to survive in media contaminated with anthracene and pyrene components. These results indicate that a mix of three types of bacteria called the consortium of marine sponge symbiont bacteria can degrade anthracene and pyrene components [37,42]

Table 4. Biodegradation parameters between the suspension of a consortium of marine sponge symbiont bacteria and waste contaminated with Anthracene and Pyrene mix

\begin{tabular}{lcccccc}
\hline \multicolumn{1}{c}{ Biodegradation Parameters } & \multicolumn{7}{c}{ Interaction Periode (days) } \\
& 0 & 5 & 10 & 15 & 20 & 25 \\
\hline Turbidity of interaction media (NTU) & 1.01 & 6,56 & 12,82 & 17,62 & 24,83 & 26,43 \\
Temperature $\left({ }^{\circ} \mathrm{C}\right)$ & 29 & 29 & 30 & 30 & 30 & 29 \\
$\mathrm{pH}$ & 6,67 & 6,68 & 6,13 & 6,10 & 6,06 & 6,43
\end{tabular}




\begin{tabular}{|c|c|c|c|c|c|c|}
\hline Abundance of gas bubbles & nt & nt & + & ++ & ++ & + \\
\hline Fermented smell & nt & nt & $\sqrt{ }$ & $\sqrt{ } \sqrt{ }$ & $\sqrt{ } \sqrt{ }$ & $\sqrt{ } \sqrt{ }$ \\
\hline nt $\quad$ : not detected & & & & & & \\
\hline$+\quad$ : gas bubbles appear less abundant & & & & & & \\
\hline$+\quad$ : looks like a lot of gas bubbles & & & & & & \\
\hline$\sqrt{ } \quad:$ weak fermentation smell & & & & & & \\
\hline$\sqrt{ } \sqrt{ }:$ strong smell of fermentation & & & & & & \\
\hline
\end{tabular}

2.5.2 Analysis of the biodegradation performance of the marine sponge symbiont consortium on the PAHs component of Anthracene and Pyrene mix

Anthracene and pyrene act as substrates that are degraded by the bacterial consortium. The number of peaks detected by running GC-MS should only be 2 (two), identified with the anthracene and pyrene components, but this did not occur as expected, where there were new peaks. There is a tendency that the longer the interaction period between the suspensions of the marine sponge symbiont bacterial consortium, the more new peaks appear, indicating that these new peaks are components of biodegradation [11,42,52]. Based on the research results, it is known that the new peaks identified are generally organic compounds of alcohol, aldehyde, carboxylic acids and some ketones and aliphatic hydrocarbon compounds. However, it cannot be estimated with certainty because GC-MS records show the suitability or quality of the components below $90 \%$ (Table 5).

The peak of anthracene and pyrene components decreased with increasing interaction time. This result indicates that the medium's abundance of anthracene and pyrene components was getting smaller due to degradation. Under the same conditions, the number of new components tends to increase, and the total concentration of components of biodegradation products also increases.

Table 5. GC-MS chromatogram data on biodegradation of a consortium of marine sponge bacterial symbionts against

\begin{tabular}{|c|c|c|c|c|c|c|}
\hline $\begin{array}{c}\text { Peak } \\
\text { number }\end{array}$ & $\begin{array}{c}\text { Retention } \\
\text { time }\end{array}$ & $\begin{array}{c}\text { Comp. peak } \\
\text { height }\left(10^{6}\right)\end{array}$ & $\begin{array}{c}\text { Quality } \\
(\%)\end{array}$ & $\begin{array}{c}\text { Total Conc. } \\
(\%)\end{array}$ & Group of comp. & $\begin{array}{l}\text { Approximate comp. } \\
\text { on the Library/ ID }\end{array}$ \\
\hline \multicolumn{7}{|c|}{ Interaction time 5 days } \\
\hline 1 & 10.287 & 0.182 & 95 & 1.057 & Aromatic & Naphthalene \\
\hline 2 & 17.468 & 0.120 & 47 & 0.424 & Aldehyde & --- \\
\hline 3 & 18,566 & 10.407 & 95 & 45,693 & Aromatic ** & Anthracene \\
\hline 4 & 21.819 & 10.902 & 96 & 51.914 & Aromatic ** & Pyrene \\
\hline 5 & 24.947 & 0.223 & 90 & 0,912 & Alcohol & Phenol \\
\hline \multicolumn{7}{|c|}{ Interaction time 10 days } \\
\hline 1 & 6.083 & 0.132 & 91 & 0.959 & Methyl & Cyclotetrasiloxane \\
\hline 2 & 17.471 & 0.794 & 53 & 3.752 & Aldehyde & --- - \\
\hline 3 & 18.559 & 8.568 & 95 & 40.589 & Aromatic ${ }^{* *}$ & Anthracene \\
\hline 4 & 21.309 & 0.239 & 78 & 1.401 & Aldehyde & 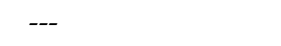 \\
\hline 5 & 21.809 & 9.113 & 96 & 50.686 & Aromatic ${ }^{* *}$ & Pyrene \\
\hline 6 & 24.944 & 0.185 & 90 & 1.070 & Alcohol & Phenol \\
\hline 7 & 26.824 & 0.240 & 62 & 1.543 & carboxylic acid & --- \\
\hline \multicolumn{7}{|c|}{ Interaction time 15 days } \\
\hline 1 & 6.088 & 0.109 & 91 & 0.558 & Organosilicon & Cyclotetrasiloxane \\
\hline 2 & 17.471 & 0.471 & 53 & 1.663 & Carboxylate & --- \\
\hline 3 & 18.564 & 7.233 & 96 & 38.311 & Aromatic $* *$ & Anthracene \\
\hline 4 & 21.311 & 0.139 & 72 & 0.561 & Indole, aldehyde & --- \\
\hline 5 & 21.818 & 8.920 & 96 & 49.619 & Aromatic ${ }^{* *}$ & Pyrene \\
\hline 6 & 22.085 & 0.080 & 93 & 0.384 & Amide & Hexadecanamide \\
\hline 7 & 23.637 & 0.187 & 91 & 0.760 & Amide & 9-octadecetamide \\
\hline 8 & 23.685 & 0.123 & 93 & 1.084 & Amide & 9-octadecenamide \\
\hline
\end{tabular}




\begin{tabular}{|c|c|c|c|c|c|c|}
\hline 9 & 24.944 & 0.506 & 93 & 1.824 & Alcohol arimatic & Phenol \\
\hline 10 & 26.823 & 0,700 & 81 & 3.236 & Carboxylate & --- \\
\hline \multicolumn{7}{|c|}{ Interaction time 20 days } \\
\hline 1 & 16.728 & 0.131 & 98 & 1.858 & Alcohol & Benzenemethanol \\
\hline 2 & 17.467 & 0.139 & 53 & 0.982 & Carboxylate & --- \\
\hline 3 & 18.553 & 4.844 & 95 & 36.105 & Aromatic ${ }^{* *}$ & Anthracene \\
\hline 4 & 20.329 & 0.141 & 46 & 0.946 & Aliphatic & --- \\
\hline 5 & 20.776 & 0.199 & 43 & 1.323 & Aliphatic & --- \\
\hline 6 & 21.803 & 7.980 & 96 & 48.603 & Aromatic $^{* *}$ & Pyrene \\
\hline 7 & 24.944 & 0.163 & 93 & 1.168 & Alcohol aromatic & Phenol \\
\hline 8 & 26.823 & 0.219 & 49 & 2.016 & Carboxylate & Tetraphtelic acid \\
\hline \multicolumn{7}{|c|}{ Interaction time 25 days } \\
\hline 1 & 17.470 & 0.242 & 64 & 1.112 & Methylene & --- \\
\hline 2 & 18.560 & 4.132 & 95 & 35.297 & Aromatic $^{* *}$ & Anthracene \\
\hline 3 & 20.332 & 0.148 & 47 & 0.697 & sulfurous acid & --- \\
\hline 4 & 20.778 & 0.332 & 47 & 1.508 & Aliphatic & --- \\
\hline 5 & 21.140 & 0.178 & 47 & 1.253 & Alcohol aromatic & --- \\
\hline 6 & 21.811 & 7.902 & 96 & 47.959 & Aromatic $^{* *}$ & Pyrene \\
\hline 7 & 24.944 & 0.126 & 78 & 0.681 & Alcohol aromatic & --- \\
\hline 8 & 26.823 & 0.234 & 91 & 1.504 & Carboxylate & Tetraphtelic acid \\
\hline Note: & --- : The c & und $\mathrm{ca}$ & 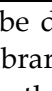 & hined & certainty becaus & the quality is below \\
\hline
\end{tabular}

2.5.3 Abundance and biodegradation products of the marine sponge symbiont consortium against the PAHs component of Anthracene and Pyrene mix

The abundance of anthracene and pyrene components seems to decrease with increasing interaction time. The decrease in the abundance value of the component is identical to the decrease in the component peak. In the same condition, new peaks appear, which indicate new components of the biodegraded organic compound group. The number of new peaks formed is relatively more with increasing interaction time. These new peaks have different retention times, peak heights vary, indicating different types and abundances of these components $[1,4,53]$. Each new component that appears has its characteristics, namely functional groups, but as a whole is a group of organic compounds. Anthracene and pyrene components are shown in red numbers, while degradation products components are shown in green numbers (Fig.4A-E). Analysis of the degraded components on the chromatogram data (Fig. 4A-E) showed differences in the number and types of components. Based on the results of the analysis, it can be stated that : (1) the number of components resulting from biodegradation tends to increase with increasing interaction time; (2) The types of components of biodegradation products are different; and (3) All biodegradation products are organic compounds with dominant characteristics in the form of hydroxyl and carbonyl functional groups.

The maximum biodegradation process was characterized by a decrease in peak height or identical to a decrease in the abundance of the maximum test PAHs that occurred at the contact time between $15-20$ days (Fig. 4C-D). The biodegradation process was relatively stagnant at the interaction period of 25 days (Fig. 4E) 

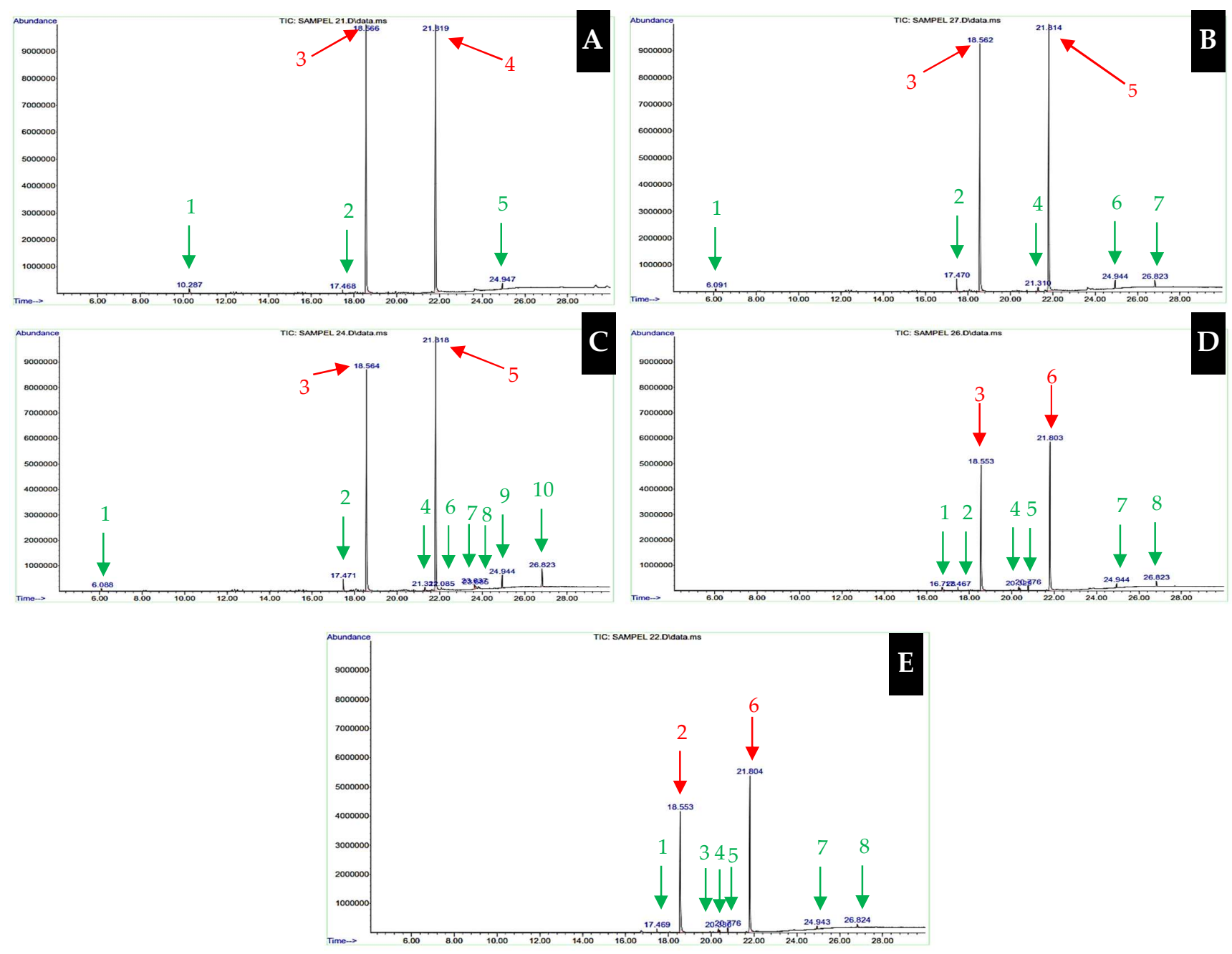

Figure 4. GC-MS chromatogram, showing the biodegradation performance of the marine sponge consortium bacterial suspension in the form of an abundance of Anthracene and Pyrene components and new peaks of biodegradation products based on interaction time. (a) the peak abundance of biodegradation at the 5-day interaction period; (b) 10 day interaction; (c) 15 day interaction; (d) 20 day interaction and (e) 25 day interaction.

\subsubsection{Functional groups of biodegradation products}

The FTIR chromatogram (Fig. 5) presents the components of biodegradation products in the form of organic compounds. Each of these is characterized by functional groups identified according to the range of wavenumbers that are identical to a particular functional group. Overall, it can be stated that the longer the interaction time, the more the number of components and the types of components identified with various variations based on the interaction time (Fig. 5A-E), although all components that appear to be dominated by organic compounds belonging to the alcohol group, aldehydes, ketones, carboxylic acids and some aromatic components $[5,8,11]$. 

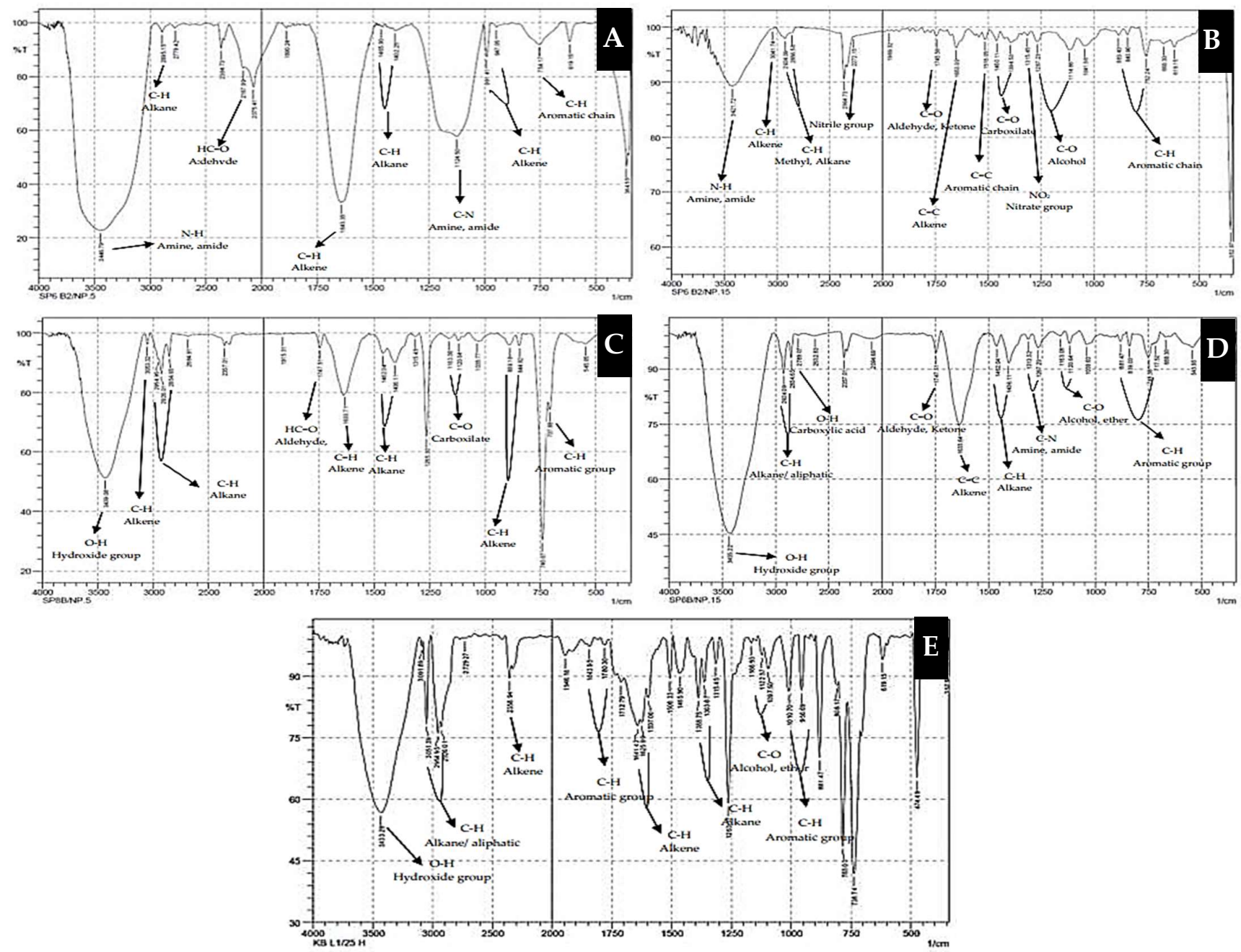

Figure 5. The FTIR chromatogram displays the functional groups of organic compounds of biodegradation products based on the interaction time. (a) 5 day interaction; (b) 10 day interaction; (c) 15 day interaction; (d) 20 day interaction and (e) 25 day interaction.

2.6. Comparison of the biodegradation of the marine sponge symbiont consortium bacteria against the components of An-trasena and Pyrena

The performance and level of biodegradation of the marine sponge symbiotic bacterial consortium against anthracene were different from that of pyrene. Comparison of the biodegradation of the bacterial consortium between anthracene and pyrene based on the abundance of components with an interaction time of 25 days (Fig.6A), the decrease in the abundance of anthracene components reached $60.30 \%$, while pyrene was only $27.52 \%$, or equivalent to a ratio of 1:2. The comparison of the bio-degradation of the bacterial consortium based on the decrease in concentration between anthracene and pyrene (Fig. 6B) reached a ratio of 1:3, i.e. the percentage decrease in the concentration of anthracene reached $21.89 \%$, while the concentration of pyrene was only $7.71 \%$. The ratio of the total concentration of PAHs (Ant. + Pyr.) that was degraded by the bacterial consortium was $17.23 \%$ (Fig. 6C), while the total concentration of the biodegradation product components formed was $17.67 \%$. These results indicate that a consortium of marine sponge symbiotic bacteria more easily degrades the anthracene component than the pyrene component $[2,11,54]$. 

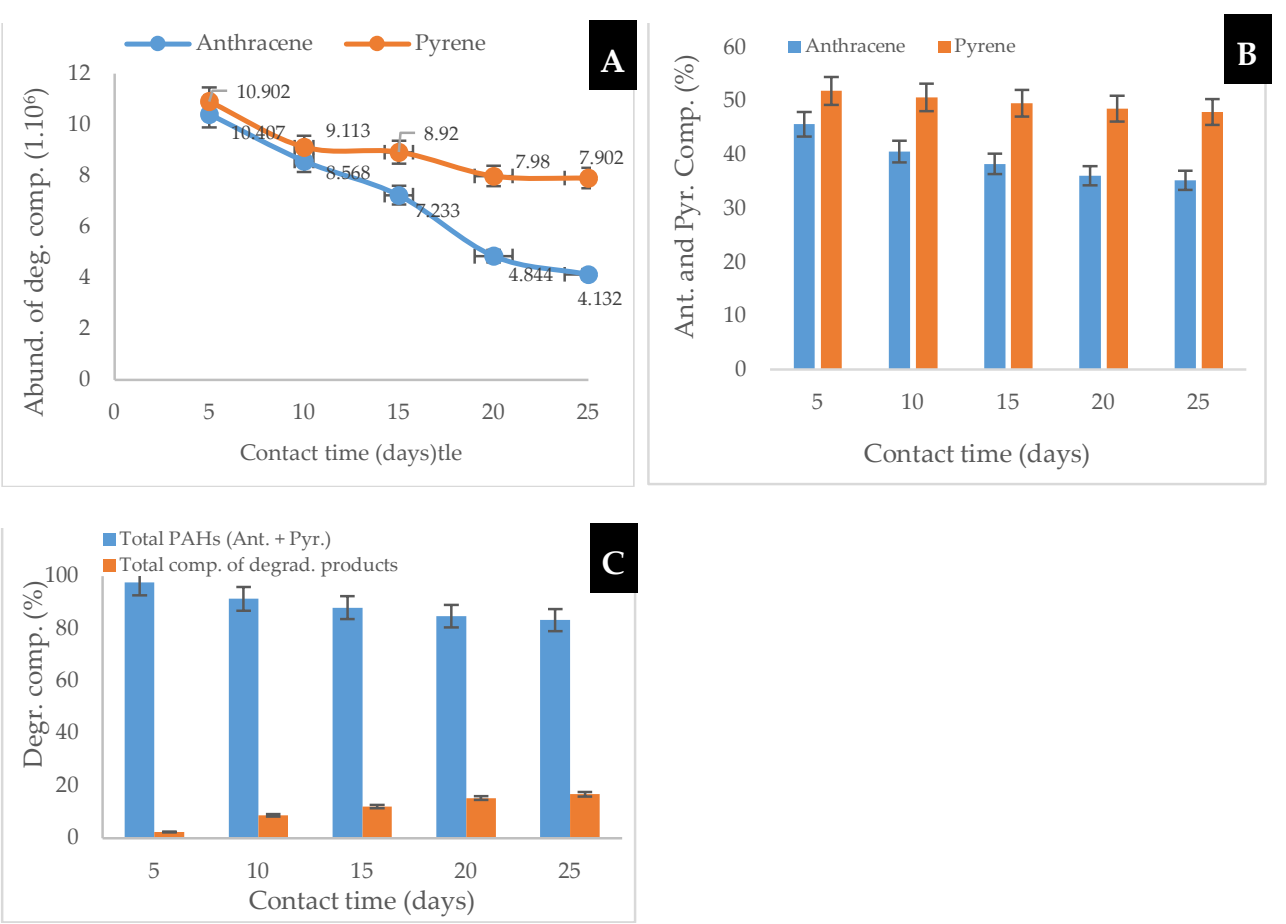

Figure 6. Biodegradation performance of a consortium of marine sponge symbiotic bacteria against Anthracene and Pyrene based on contact time. Fig. 6A. Decreased abundance of Anthracene and Pyrene components; Fig. 6B. Reduction of Anthracene and Pyrene components; and Fig. 6C. Increase in components of biodegradation products and decrease in total PAHs (Anthracene and Pyrene)

\section{Discussion}

The seawater conditions at the sponge sampling point showed good quality. This is based on data on salinity, $\mathrm{pH}$, electrical conductivity, total dissolved solids (TDS) (Table 1), but it does not mean that the seawater is free from contamination with hydrocarbon components. The results of the morphological analysis of marine sponges showed that the three types of marine sponges that were the source of bacterial isolates had a characteristic slimy body surface (Fig. 1-3). The mucus on the surface of the sponge body is thought to be a substance produced by symbiotic bacteria for self-protection and adaptation to the dynamics that occur in the sponge's growth habitat $[5,15,54]$. The results of the phenotypic analysis (Table 2) indicated that the mix of the three isolates in the form of a bacterial consortium was estimated to meet the requirements for carrying out the PAH biodegradation process through the mechanism of destruction of the molecular structure of the aromatic ring. Genotypic analysis was carried out to ascertain the character of the three types of isolates used in carrying out the biodegradation function of PAHs so that data on the strains of bacterial symbiont isolates were obtained (Table 3).

The combination of three types of analyzes carried out on both marine sponges and isolated bacteria (Figs 1-3; Tables 2 and 3) indicates the presence of a common thread or strong relationship indicating that marine sponge symbiont bacteria that have the ability to carry out PAH biodegradation functions are bacteria which is obtained from a type of sponge whose body is slimy or the surface of the body of a sponge is dark in colour. One of the novelties of this research is that it provides an understanding and can be used as a method or guideline in tracing potential bacteria from marine sponges that can carry out the biodegradation function of hydrocarbon components, especially PAHs, making it easier for us to compile data and collections of PAH biodegradative bacteria $[11,37,39]$.

The reference state that the biodegradation process of PAHs components (anthracene and pyrene) by a consortium of marine sponge symbiont bacteria has been running, it can be seen from the data and observes several indicators, including turbidity values, changes 
in temperature, $\mathrm{pH}$, gas bubbles and the smell of the interaction media fermentation (Table 4) [56]. Another analysis that can be used as a reference is the degradation of anthracene and pyrene by a consortium of sponge symbiont bacteria by observing the decrease in the abundance of anthracene and pyrene substrates in the media after the interaction lasted several days (Table 5). The abundances referred to are peak height (Fig. 4A-E), change in the percentage of a substrate as a degraded component (Table 5), the formation of new peaks as a component of biodegradation products (Fig. 4) and the percentage of total components of biodegradation products (Table 5). The new peaks formed are simple organic compounds in the form of alcohols, aldehydes, ketones, carboxylic acids, aromatic components with their respective characteristics (Table 4; Fig. 5) [2,40,57].

The anthracene component is more easily degraded by a consortium of marine sponge bacterial symbionts than pyrene (Fig. 6). Theoretically, this can be accepted with several assumptions: (1) the toxicity level of pyrene is higher than anthracene, so that bacterial cells are more difficult to last longer in the biodegradation process compared to anthracene; (2) the structure of the pyrene molecule is more stable than that of anthracene so that bacteria are more difficult to destroy the pyrene molecule than the anthracene molecule, (3) the number of pyrene aromatic rings is more, and it forms a compact structure, the resonance can run longer than the number of rings and resonance anthracene so that bacterial cells need a relatively long time to degrade the pyrene molecule or aromatic ring compared to anthracene, (4) Acid compounds, degradation products that are formed as well as limiting substances for the biodegradation process. In this condition, bacterial cells can experience mass and sudden death, or bacterial cells have difficulty dividing themselves further $[7,16,37,58]$

\section{Materials and Methods}

\subsection{Materials}

The materials used include three types of marine sponges coded Sp1 (Niphates sp.), Sp2 Hyrtios erectus), Sp3 (Clathria (Thalysias) reinwardtii, (Fig. 1-3), which are collected by researchers [11,29, 42]. Marine sponge symbiont bacteria code Sp1-Bc, Sp2-Ps, Sp3-Ac, (Table 3), methanol pa, n-hexane for GC, anthracene cas number 000120-12-7and pyrene cas number 000129-00-0 (Supelco), Na2SO 4 pa, aquabides, physiological $0.9 \% \mathrm{NaCl}$, (commercially obtained), set of materials for sponge morphology analysis, set of materials for standard biochemical tests following the guidelines in Microbiology: A Laboratory Manual [59] and set of materials for genotypic analysis of bacterial isolates. Bacterial isolates of marine sponge symbionts are the research stock, part of a previous publication $[11,29,32,37]$

\subsection{Sampling point characteristics}

Parameters observed and measured were related to seawater conditions at the sponge sampling point, including coordinates, salinity, $\mathrm{pH}$, TDS, HDL, the distance from the sampling point to the nearest shoreline and the sampling depth from sea level (Table 1). All data displayed has not been previously published. Determination of sampling points and sampling techniques are guided by fisheries and marine experts who are members of a team of Non-Governmental Organizations concerned with marine life.

\subsection{Marine sponge morphology}

Morphology, cell structure, and types of sea sponge samples in the study were analyzed at the Microbiology Laboratory of Sebelas Maret University, Surakarta, Central Java. Sponge types and morphological data are part of the researcher's stock from previous publications [11,29,32,37,42].

\subsection{Isolation and phenotypic analysis of isolates of marine sponge symbiont bacteria}


Isolation of bacteria using Swab method, purification by a direct plating method, morphological analysis by direct observation, Gram staining, phenotypic analysis and determination of isolates of marine sponge symbiont bacteria following the Laboratory Manual procedure [59]. The data showed (Table 2) is the researcher's stock, part of previous publications $[29,32,37]$.

\subsection{Isolate genotypic analysis}

Character and species of isolates of marine sponge symbiont bacteria were determined through genotypic analysis to see the sequence and sequence of nitrogen base pairs using the PCR method (Table 3). The data displayed is the researcher's stock and is part of the previous publication $[11,29,32,37,42]$

\subsection{Biodegradation interactions and processes}

\subsubsection{Interaction of biodegradation components}

Selected bacterial isolates (Sp1-Bc, Sp2-Ps, Sp3-Ac) from the research stock [11,29,37], were cultured respectively. Change the culture results in the form of a bacterial suspension. Each type of bacterial suspension, pipette $10 \mathrm{~mL}$ and put in an Erlenmeyer flask, diluted to $100 \mathrm{~mL}$, homogenized and adapted for $1 \times 24$ hours in an incubator. Mix the bacterial suspension (consortium), $5 \mathrm{~mL}$ pipette and put it in a row of 15 different test tubes, then incubate for $1 \times 2$ hours in an incubator: prepared anthracene and pyrene 1000 ppm each, both mixed together. A total of $2 \mathrm{~mL}$ of mixed PAHs (Ant + Pyr) were put in each test tube which had previously been filled with bacterial suspension. Interaction between bacterial suspension and PAHs aerated on a shaker incubator at $200 \mathrm{rpm}$. The interaction time is 25 days, and every five days observations are made, biodegradation parameters are measured $[4,11,58]$.

\subsubsection{Parameters of biodegradation of PAHs by bacteria}

Measurement of the parameters of the biodegradation of bacterial suspensions against PAHs was carried out every five days of interaction, using appropriate measuring instruments and also direct observations for the parameters of the abundance of gas bubbles formed and the odor of fermentation (Table 4) [11,12]

\subsubsection{Biodegradation performance of PAHs by bacteria}

Measurement of abundance and components of biodegradation products was carried out every five days of contact, carried out by extracting components of anthracene and pyrene that were not degraded, as well as components of biodegradation products using n-hexane. The n-hexane extract was water-free using $\mathrm{Na}_{2} \mathrm{SO}_{4}$ and ready to run using GCMS (Table 5, Fig. 4A-E) [1,37]

4.6.4 Functional groups for biodegradation of PAHs by bacteria

Aqueous-free n-hexane extract was partially used for the determination of the functional groups of each biodegradation product using the FTIR instrument (Fig 5A-E)

\subsection{Comparison of biodegradation rates of components between sene and pyrene}

The variables reviewed in comparing the biodegradation level of the bacterial consortium against anthracene and pyrene, including the analysis of the decrease in peak height of the degraded components based on the interaction time according to the equation:

$$
\text { Abund.of degr.comp. }(\%)=\frac{(\text { peak height }) \text { no-(peak height }) n t}{(\text { peak height }) \text { no }} \times 100 \% \text {, }
$$

where: no and nt represent the initial and final peak heights of the biodegradation process $[7,14]$ respectively. The decrease in the concentration of the substrate component (anthracene or pyrene) that underwent biodegradation was determined using the equation:

$$
\text { Conc. of degr.comp.X }(\%)=\frac{(\text { initial conc.of comp.X })-(\text { final conc. of comp.X })}{(\text { Total conc. of comp. })} \times 100 \% \text {, }
$$


where: $\mathrm{X}$ is the component of anthracene or pyrene PAHs that undergoes degradation based on an interaction time of 25 days [31]. Determination of the concentration comparison of the components of the biodegradation product of the sponge symbiont bacteria consortium against all identified components, using the equation:

$$
\text { Cerc. of comp. biodegr. products }(\%)=\frac{\text { Total comp. of biodegr. products }}{\text { Total conc. of comp. }} \times 100 \% \text {, }
$$

Equation (1) was used to calculate the degradation rate of anthracene and pyrene by a consortium of bacteria based on the recorded peak height data (Fig. 6A; Fig. 4A-E and Table 5). Equation (2) was used to determine the concentration of the degraded anthracene and pyrene components (Fig. 6B) and equation (3) to determine the total concentration of the components of the biodegradation product (Fig. 6C). Each result obtained is compared between the two to get the value of the biodegradation ratio.

\section{Conclusions}

Based on the results obtained and the analysis that has been carried out, several things can be stated: The bacterial consortium succeeded in degrading $21.89 \%$ of the anthracene component and $7.71 \%$ of the pyrene component. The total concentration of biodegradation product components reached $17.67 \%$. Several types of organic compounds from biodegradation products found in this study include alcohol, aldehydes, carboxylic acids, ketones and a small number of aromatic components. The use of a bacterial consortium was low successful in increasing the level of biodegradation of the tested PAHs, compared to the use of single bacteria, presumably due to competition between bacterial cells in the media. Acid components of biodegradation products have the effect of decreasing the strength of bacterial cells in continuing the biodegradation process. The flow of the research carried out indicated that the search for sponge symbiont bacteria has the potential for biodegradation of PAHs by selecting sponges whose body surface is covered with mucus.

\section{Patents}

There are three patent works that are part of this manuscript, in the public testing process stage at the Ministry of Law and Human Rights of the Republic of Indonesia, each with the title: (1) Performance of microsymbionts from marine sponge culture as a biodegradator of polycyclic aromatic hydrocarbons (PAH), code registration: P15202008653; (2) Tracing method for bacterial isolates isolated from marine sponges as biodegradator material for polycyclic aromatic hydrocarbons (PAH), registration code: S15201907661 and (3) New metal-lo-clastic bacterial species cultured from marine sponges as biomaterials -adsorbent of several kinds of heavy metals, registration code: P15202008653.

Author Contributions: For research articles with several authors, a short paragraph specifying their individual contributions must be provided. The following statements should be used "Conceptualization, I.M., K.N., and M.K..; methodology; I.M., R.A., and K.N.; validation, Rh.A., R.A. and M.P.; formal analysis, I.M. and A.A.; investigation, I.M. and M.P.; resources, I.M. and M.K.; data curation, K.N.; writing - original draft preparation, I.M.; writing - review and editing, K.N. and Rh.A.; visualization, I.M.; supervision, R.A.; project administration, M.P. and A.A.. All authors have read and agreed to the published version of the manuscript."

Funding; This research was supported by the DRPM of the Ministry of Research, Technology, and Higher Education of the Republic of Indonesia, under contract number: B/87/E3/RA.00/2020, dated January 28, 2020, and Fajar University, under Work Implementation Order number: 25 /AI/LPPMUNIFA/ IV/2020, dated April 21, 2020. 
Institutional Review Board Statement: Review and publication of this manuscript statement need not state the Institutional Review Board, because all of the data and information that is presented is the result of research that not involve animals and humans as test material.

Informed Consent Statement: Not applicable

Data Availability Statement: Not applicable

Acknowledgments: We acknowledge the support of the Hasanuddin, Biochemistry Laboratory Manager, Department of Chemistry, for the chance to utilize the instrument facilities. The Makassar Plantation Product Industry Center (BBIHP) is the research's implementing partner.

Conflicts of Interest: All authors declare that they have no conflicts of interest in the preparation and publishing of this paper.

Sample Availability: The sample is provided by the author. There are materials provided by the author, especially materials that are not available in the laboratory. Samples of the compounds ... are available from the authors.

\section{Reference}

1 Bendouz, M.; Dionne, D.; Tran, L.H.; Coudert, L.; Mercier, G.; Blais, J.F. Polycyclic Aromatic Hydrocarbon Oxidation from Concentrates Issued from an Attrition Process of Polluted Soil Using the Fenton Reagent and Permanganate. Water, Air, and Soil Pollution. 2017, 228, 115. https://doi.org/10.1007/s11270-017-3292-x

2 Bezza, F.A.; Chirwa, E.M.N. Biosurfactant-enhanced bioremediation of aged polycyclic aromatic hydrocarbons (PAHs) in creosote contaminated soil Fisseha. Chemosphere. 2016, 144, 635-644. https://doi.org/10.1016/j.chemosphere.2015.08.027; P.Mid: 26408261

3 Dadrasnia, A.; Usman, M.M.; Lim, K.T.; Farahiyah, F.H.; Rodzhan, N.Sb.M.; Karim, S.H.A.; Ismail, S. Bio-Enhancement of Petroleum Hydrocarbon Polluted Soil Using Newly Isolated Bacteria. Polycyclic Aromatic Compounds, 2020, 40, 484-493. https://doi.org/10.1080/10406638.2018.1454966

4 Fang, H.; Shi, Y.; Zhou, M.; Niu, Q. Influence of n-Hexadecane and Naphthalene on Anaerobic Digestion: Kinetic Simulation, DOM Variation and Microbial Community Assessment. GEESD, IOP, Conf. Series: Earth and Environmental Science, 2020, 555, 012038. https://doi.org/10.1088/1755-1315/555/1/012038

5 Ja 'nczuk, B.; Szymczyk, K.; Zdziennicka, A. Adsorption Properties of Hydrocarbon and Fluorocarbon Surfactants Ternary Mixture at the Water-Air Interface. Molecules, 2021, 26, 4313. https://doi.org/10.3390/molecules26144313; P.Mid: 34299588 P.M.Cid: PMC8304021

6 Khabouchi, I.; Khadhar, S.; Chaouachi, D.; Chekirbene, A.; Doumenq, P. Study of organic pollution in superficial sediments of Meliane river catchment area : aliphatic and polycyclic aro-matic hydrocarbons Study of organic pollution in superficial sediments of Meliane river catchment area: aliphatic and polycyclic aromatic hy. Enviroment Monit Assess. 2020, April, $282-290$. https://doi.org/10.1007/s10661-020-8213-6; P.Mid: 32285216

7 Lu, C.; Hong, Y.; Liu, J.; Gao, Y.; Ma, Z.; Yang B.; Ling, W.; Waigi, M.G. A PAH-degrading bacterial community enriched with contaminated agricultural soil and its utility for microbial bioremediation. Environmental Pollution, 2019, 251, 773-782. https://doi.org/10.1016/j.envpol.2019.05.044; P.Mid: 31121542

8 Medi', A.; Lješević, M.; Inui, H.; Stojanovi', K.; Karad`zi', I.; Be`skoski,d, V.; Koji, I. Efficient biodegradation of petroleum: N alkanes and polycyclic aromatic hydrocarbons by polyextremophilic Pseudomonas aeruginosa san ai with multidegradative capacity. RSC Adv. 2020, 10(24), 14060-14070. https://doi.org/10.1039/C9RA10371F

9 Parhamfar, M.; Abtahia, H.; Godinib, K.; Saeedi, R.; Sartaje, M.; Villaseñorf, J.; Coulong, F.; Kumarg, V.; Soltanighiash, T.; Radi, E.G.; Koolivand, A. Biodegradation of heavy oily sludge by a two-step inoculation composting process using synergistic effect of indigenous isolated bacteria. Process Biochem. 2020, 91, 223-230. https://doi.org/10.1016/j.procbio.2019.12.014

10 Laothamteep, N.; Kawano, H.; Vejarano, F.; Minakuchi, C.S.; Shintani, M.; Nojiri, H.; Pinyakong, O. Effects of environmental factors and coexisting substrates on PAH degradation and transcriptomic responses of the defined bacterial consortium OPK. Environ Pollut. 2021, 277, 116769. https://doi.org/10.1016/j.envpol.2021.116769; P.Mid: 33676341

11 Marzuki, I.; Kamaruddin, M.; Ahmad, R. Identification of marine sponges-symbiotic bacteria and their application in degrading polycyclic aromatic hydrocarbons. Biodiversitas. 2021, 22(3), 1481-1488. https://doi.org/10.13057/biodiv/d220352

12 Abass, O.K.; Zhuo, M.; Zhang, K. Concomitant degradation of complex organics and metals recovery from fracking wastewater: Roles of nano zerovalent iron initiated oxidation and adsorption. Chem Eng J. 2017, 328, 159-171. https://doi.org/10.1016/j.cej.2017.07.030

13 Nursid, M.; Marraskuranto, E.; Atmojo, K.B.; Hartono, T.M.P.; Meinita, M.D.N. Investigation on antioxidant compounds from Marine Algae Extracts collected from Binuangeun Coast, Banten, Indonesia. Squalen Bull Mar Fish Postharvest Biotechnol. 2016, 11(2), 59-67. https://doi.org/10.15578/squalen.v11i2.243 
14 Onwosia, C.O.; Odibob, F.-J.K.; Enebechia, C.K.; Nwankwegub, A.S.; Ikeleb, A.I.; Okehc, O.C. Soil and Sediment Contamination: An International Bioremediation of Diesel-contaminated Soil by Composting with Locally Generated Bulking Agents Bioremediation of Diesel-contaminated. Soil Sediment Contam. 2017, 0(0), 1-19. https://doi.org/10.108015320383.2017.1348337

15 Košnář, Z.; Částková, T.; Wiesnerová, L.; Praus, L.; Jablonský, I.; Koudela, M.; Tlustoš, P. Comparing the removal of polycyclic aromatic hydrocarbons in soil after different bioremediation approaches in relation to the extracellular enzyme activities. $J$ Environ Sci. 2018, XX, 1-10. https://doi.org/10.1016/j.jes.2018.05.007; P.Mid: 30528015

16 Yetti, E.; Thontowi, A.; Yopi, Y.; Lisdiyanti, P. Screening of Marine bacteria capable of degrading various polyaromatic hydrocarbons. Squalen Bull Mar Fish Postharvest Biotechnol. 2015, 10(3), 121-127. https://doi.org/10.15578/squalen.v10i3.123

17 Obire, O.; Aleruchi, O.; Wemedo, S. Fungi in Biodegradation of Polycyclic Aromatic Hydrocarbons in Oilfield Wastewater. Acta Sci Microbiol. 2020, 3(4), 220-224. https://doi.org/10.31080/ASMI.2020.03.0572

18 Sinsona, M.-J.; Juinio, -M.M.A. Effects of sediment enrichment with macroalgae, Sargassum spp., on the behavior, growth, and survival of juvenile sandfish, Holothuria scabra. Aquac Reports. 2018, 12, 56-63. https://doi.org/10.1016/j.aqrep.2018.09.002

19 Araújo, S.C. da S.; Silva, -P.R.C.B.; de Lima, D.C.; da fonsêca, M.M.B.; Araújo, W.J.; da Silva, U.B.; Amanda, P. napp.; Pereira, E.; Vainstein, M.H.; Agnez, -L.L.F. MBSP1: a biosurfactant protein derived from a metagenomic library with activity in oil degradation. Sci Reports Natureresearch. 2020, 10, 1340-1352. https://doi.org/10.1038/s41598-020-58330-x; P.Mid: 31992807; P.M.Cid: PMC6987170

20 Campana, S.; Hudspith, M.; Lankes, D.; de Kluijver, A.; Demey, C.; Schoorl, J.; Absalahh, S.; der Meer, M.T.J.; Mueller, B.; de Goeij, J.-M. Processing of Naturally Sourced Macroalgal- and Coral-Dissolved Organic Matter (DOM) by High and Low Microbial Abundance Encrusting Sponges. Front Mar Sci. 2021, 8, 1-14. https://doi.org/10.3389/fmars.2021.640583

21 Gu, B.; Li, F.; Liu, Y.; Mao, L.; Tao, H. Effect of Vegetable Growth on Content and Composition of Antibiotics in Litopenaeus vannamei Pond Sediments in Crop/Aquacultural Rotation Process. Sustainability. 2021,13(15), 8400. https://doi.org/10.3390/su13158400

22 Maldonado, M.; López, -A.M.; Busch, K.; Slaby, B.M.; Bayer, K.; Beazley, L.; Hentschel, U.; Kenchington, E.; Rapp, H.T. A Microbial Nitrogen Engine Modulated by Bacteriosyncytia in Hexactinellid Sponges: Ecological Implications for Deep-Sea Communities. Front Mar Sci. 2021, 8, 1-35. https://doi.org/10.3389/fmars.2021.638505

23 Morganti, T.M.; Ribes, M.; Yahel, G.; Coma, R. Size Is the Major Determinant of Pumping Rates in Marine Sponges. Front Physiol. 2019, 10, 1474. https://doi.org/10.3389/fphys.2019.01474; P.Mid: 31920688; P.M.Cid: PMC6917621

24 Orani, A.M.; Barats, A.; Vassileva, E.; Thomas, O.P. Marine sponges as a powerful tool for trace elements biomonitoring studies in coastal environment. Mar Pollut Bull. 2018, 131, 633-645. https://doi.org/10.1016/j.marpolbul.2018.04.073; P.Mid: 29886991

25 Page, H.N.; Hewett, C.; Tompkins, H.; Hall, E.R. Ocean acidification and direct interactions affect coral, macroalga, and sponge growth in the florida keys. J Mar Sci Eng., 2021, 9(7), 739. https://doi.org/10.3390/jmse9070739

26 Pita, L.; Rix, L.; Slaby, B.M.; Franke, A.; Hentschel, U. The sponge holobiont in a changing ocean: from microbes to ecosystems. Microbiome. 2018, 6(1), 46. https://doi.org/10.1186/s40168-018-0428-1; P.Mid: 29523192; P.M.Cid: PMC5845141

27 Turon, M.; Cáliz, J.; Garate, L.; Casamayor, E.O.; Uriz, M.J. Showcasing the role of seawater in bacteria recruitment and microbiome stability in sponges. Sci Rep. 2018, 8(1), 15201. https://doi.org/10.1038/s41598-018-33545-1; P.Mid: 30315194; P.M.Cid: PMC6185911

28 Campana, S.; Busch, K.; Hentschel, U.; Muyzer, G.; de Goeij, J.M. DNA-stable isotope probing (DNA-SIP) identifies marine sponge-associated bacteria actively utilizing dissolved organic matter (DOM). Environ Microbiol. 2021, 00, 1-16. https://doi.org/10.1111/1462-2920.15642; P.Mid: 34159693

29 Marzuki, I.; Sinardi, S.; Pratama, I.; Chaerul, M.; Paserangi, I.; Kamaruddin, M.; Asaf, R. Performance of sea sponges micro symbionts as a biomaterial in biodegradation naphthalene waste of modified. In: The 5th Int. Seminar on Sustainable Urban Dev. Jakarta, Indonesia, 5 August 2020, IOP Conf. Series: Earth and Env. Sci. 2021, 737, 012016. https://doi.org/10.1088/1755$\underline{1315 / 737 / 1 / 012016}$

30 Costa, G.; Violi. B.; Bavestrello, G.; Pansini, M.; Bertolino, M. Aplysina aerophoba (Nardo, 1833) (Porifera, Demospongiae): an unexpected miniaturised growth form the tidal zone of Mediterranean caves: morphology and DNA barcoding. Eur Zool J. 2020, 87(1), 73-81. https://doi.org/10.1080/24750263.2020.1720833

31 Baquiran, J.I.P.; Nada, M.A.L.; Posadas, N.; Manogan, D.P.; Cabaitan, P.C.; Conaco, C. Population structure and microbial community diversity of two common tetillid sponges in a tropical reef lagoon. PeerJ. 2020, 4, 1-25. https://doi.org/10.7717/peerj.9017; P.Mid: 32351788; P.M.Cid: PMC7183310

32 Marzuki, I.; Daris, L.; Nisaa, K.; Emelda, A. The power of biodegradation and bio-adsorption of bacteria symbiont sponges sea on waste contaminated of polycyclic aromatic hydrocarbons and heavy metals. In: Int. Conf. on Fisheries and Marine, Ternate, Maluku, Indonesia, 13 July 2020. IOP Conf. Series: Earth and Env. Sci,. 2020, 584, 012013. https://doi.org/10.1088/1755$\underline{1315 / 584 / 1 / 012013}$

33 Yang, Q.; Franco, C.M.M.; Lin, H.W.; Zhang, W. Untapped sponge microbiomes: Structure specificity at host order and family levels. FEMS Microbiol Ecol. 2019, 95(9), 1-17. https://doi.org/10.1093/femsec/fiz136; P.Mid: 31494678

34 Lavy, A.; Keren, R.; Haber, M.; Schwartz, I.; Ilan, M. Implementing sponge physiological and genomic information to enhance the diversity of its culturable associated bacteria. FEMS Microbiol Ecol. 2014, 87(2), 486-502. https://doi.org/10.1111/15746941.12240; P.Mid: 24164535 
35 Fu, X.; Wang, H.; Bai, Y.; Xue, J.; Gao, Y.; Hu, S.; Wu, T.; Sum, J. Systematic degradation mechanism and pathways analysis of the immobilized bacteria: Permeability and biodegradation, kinetic and molecular simulation. Environ Sci Ecotechnology. 2020, 2,100028. https://doi.org/10.1016/j.ese.2020.100028

36 Su, X.M.; Bamba, A.M.; Zhang, S.; Zhang, Y.G.; Hashmi, M.Z.; Lin, H.J.; Ding, L.X. Revealing potential functions of VBNC bacteria in polycyclic aromatic hydrocarbons biodegradation. Lett Appl Microbiol. 2018, 66(4), $277-283$. https://doi.org/10.1111/lam.12853; P.Mid: 29350767

37 Marzuki, I.; Daris, L.; Yunus, S.; Riana, A.D. Selection and characterization of potential bacteria for polycyclic aromatic biodegradation of hydrocarbons in sea sponges from Spermonde Islands, Indonesia. AACL Bioflux. 2020, 13(6), 3493-3506.

38 Rua, C.P.J.; de Oliveira, L.S.; Froes, A.; Tschoeke, D.A.; Soares, A.C.; Leomil, L.; Gregoracci, G.B.; Coutinho, R.; Hajdu, E.; Thompson, C.C.; Berlinck, R.G.S.; Thompson, F.L. Microbial and Functional Biodiversity Patterns in Sponges that Accumulate Bromopyrrole Alkaloids Suggest Horizontal Gene Transfer of Halogenase Genes. Microb Ecol Journal-Springer Sci Media. 2018, (March). https://doi.org/10.1007/s00248-018-1172-6; P.Mid: 29546438

39 Al-Dhabaan, F.A. Morphological, biochemical and molecular identification of petroleum hydrocarbons biodegradation bacteria isolated from oil polluted soil in Dhahran, Saud Arabia. Saudi J Biol Sci. 2019, $26(6), 1247-1252$. https://doi.org/10.1016/j.sjbs.2018.05.029; P.Mid:.31516354; P.M.Cid: PMC6733695

40 Miao, L.L.; Qu, J.; Liu, Z.P. Hydroxylation at Multiple Positions Initiated the Biodegradation of Indeno[1,2,3-cd]Pyrene in Rhodococcus aetherivorans IcdP1. Front Microbiol. 2020, 11, 1-13. https://doi.org/10.3389/fmicb.2020.568381; P.Mid: 33072027; P.M.Cid: PMC7536264

41 Cui, X.; Tian, J.; Yu, Y.; Chand, A.; Zhang, S.; Meng, Q.; Li, X.; Wang, S. Multifunctional graphene-based composite sponge. Sensors (Switzerland). 2020, 20(2), 329. https://doi.org/10.3390/s20020329; P.Mid: 31936007; P.M.Cid: PMC7014689

42 Marzuki, I.; Ali, M.Y.; Syarif, H.U.; Gusty, S.; Ritnawati, R.; Daris, L.; Nisaa, K. Investigation of Biodegradable Bacteria as Bio indicators of the Presence of PAHs Contaminants in Marine Waters in the Marine Tourism Area of Makassar City. In: The 6th Int. Conf. on Tropical and Coastal Region Eco, .Semarang, Indonesia, 27-28 Oct. 2020; IOP Conf. Series: Eart Environ. Sci., 2021, 750, 012006. https://doi.org/10.1088/1755-1315/750/1/012006

43 Khan, M.N.; Ullah, H.; Naeem, S.; Uddin, J.; Hamid, Y.; Ahmad, W.; Ding, J. Remediation of Emerging Heavy Metals from Water Using Natural Adsorbent: Adsorption Performance and Mechanistic Insights. Sustainability. 2021, $13(\mathrm{~V}): 8817$. https://doi.org/10.3390/su13168817

44 Siahaya, N.; Noor, A.; Sukamto, N.; de Voogd, N. A preliminary effort to assign sponge (\&lt;i\&gt;Callispongia sp\&lt;/i\&gt;) as trace metal biomonitor for $\mathrm{Pb}, \mathrm{Cd}, \mathrm{Zn}$, and $\mathrm{Cr}$, an environmental perspective in Hative gulf waters Ambon. Adv Biol Chem. 2013, 3(6), 549-552. https://doi.org/10.4236/abc.2013.36062

45 Melawaty, L.; Noor, A.; Harlim, T.; de Voogd, N. Essential metal Zn in sponge Callyspongia aerizusa from Spermonde Archipelago. Adv Biol Chem. 2014, 4(1), 86-90. https://doi.org/10.4236/abc.2014.41012

46 Karimpour, M.; Ashrafi, S.D.; Taghavi, K.; Mojtahedi A.; Roohbakhsh, E.; Naghipur, D. Adsorption of cadmium and lead onto live and dead cell mass of Pseudomonas aeruginosa: A dataset. Elsevier. 2018, 18, 1185-1192. https://doi.org/10.1016/j.dib.2018.04.014; P.Mid:.29900292; P.M.Cid: PMC5997576

47 Schmittmann, L.; Jahn, M.T.; Pita, L.; Hentschel, U. Decoding cellular dialogues between sponges, bacteria, and phages. In: Cellular Dialogues in the Holobiont. 2020, 49-63. https://doi.org/10.1201/9780429277375-4

48 Bart, M.C.; Hudspith, M.; Rapp, H.T.; Verdonschot, P.F.M.; de Goeij, J.M. A Deep-Sea Sponge Loop? Sponges Transfer Dissolved and Particulate Organic Carbon and Nitrogen to Associated Fauna. Front Mar Sci. 2021, 8, 1-12. https://doi.org/10.3389/fmars.2021.604879

49 Arjuna, A.; Olson, M.T.; Tokman, S.; Walia, R.; Mohanakumar, T.; Hashimi, A.Samad.; Smith, M.A.; Bremner, R.M.; Omar, A.; Norton, N. Antibody-Mediated Rejection and Sponge Effect in a Redo Lung Transplant Recipient. Case Rep Transplant. 2021, ID 6637154, 1-4. https://doi.org/10.1155/2021/6637154; P.Mid: 34221532; P.M.Cid: PMC8213496

50 Weigel, B.L.; Erwin, P.M. Effects of reciprocal transplantation on the microbiome and putative nitrogen cycling functions of the intertidal sponge, Hymeniacidon heliophila. Sci Rep. 2017, 7, 1-12. https://doi.org/10.1038/srep43247; P.Mid: 28233813; P.M.Cid: PMC5324122

$51 \mathrm{Xu}, \mathrm{X} . ; \mathrm{Hu}, \mathrm{J} . ; \mathrm{Lu}, \mathrm{H}$. Histological observation of a gelatin sponge transplant loaded with bone marrow-derived mesenchymal stem cells combined with platelet-rich plasma in repairing an annulus defect. PLoS One. 2017, 12(2), 1-15. https://doi.org/10.1371/journal.pone.0171500; P.Mid: 28178294; P.M.Cid: PMC5298264

52 Guo, J.; Wen, X. Performance and kinetics of benzo(a)pyrene biodegradation in contaminated water and soil and improvement of soil properties by biosurfactant amendment. Ecotoxicol Environ Saf. 2021, $207,111292$. https://doi.org/10.1016/j.ecoenv.2020.111292; P.Mid: 32919193

53 Ray, M.; Kumar, V.; Banerjee, C.; Gupta, P.; Singh, S.; Singh, A. Investigation of biosurfactants produced by three indigenous bacterial strains, their growth kinetics and their anthracene and fluorene tolerance. Ecotoxicol Environ Saf. 2021, $208,111621$. https://doi.org/10.1016/j.ecoenv.2020.111621; P.Mid: 33396141

54 Smułek, W.; Sydow, M.; Matejuk,Z.J.; Kaczorek, E. Bacteria involved in biodegradation of creosote PAH - A case study of longterm contaminated industrial area. Ecotoxicol Environ Saf. 2020, 187, 109843. https://doi.org/10.1016/j.ecoenv.2019.109843; P.Mid: 31678701 
55 Tziveleka, L.-A.; Ioannou, E.; Tsiourvas, D.; Berillis, P.; Foufa, E.; Roussis, V. Collagen from the marine sponges Axinella cannabina and Suberites carnosus: Isolation and morphological, biochemical, and biophysical characterization. Mar Drugs. 2017, 15(6), 152. https://doi.org/10.3390/md15060152; P.Mid: 28555046; P.M.Cid: PMC5484102

56 Arroyo, A.; Provoste, F.; Rodríguez, M.; Prieto, A.L. A mechanistic model to assess the fate of naphthalene and benzo(A)pyrene in a chilean wwtp. Processes. 2021, 9(8), 1313. https://doi.org/10.3390/pr9081313

57 Scheuch, G.A.; Zuñiga, J.R.; Fuentes, E.; Bravo, D.; Donoso, J.M.P. Effect of co-contamination by PAHs and heavy metals on bacterial communities of diesel contaminated soils of south shetland islands, antarctica. Microorganisms. 2020, 8(11),1-17. https://doi.org/10.3390/microorganisms8111749; P.Mid:.33171767; P.M.Cid: PMC7695015

58 Marzuki, I.; Pratama, I.; Ismail, H.E.; Paserangi, I.; Kamaruddin, M.; Chaerul, M.; Ahmad, R. The Identification and Distribution Components of Polycyclic Aromatic Hydrocarbon Contaminants at the Port of Paotere, Makassar, South Sulawesi. In: The 1st Int. Conf. on Biotech.and Food Sciences, Surabaya, Indonesia, 11 Sept. 2021. IOP Conf. Series: Earth and Env. Sci. IOP Publishing 2021, 679, 012017. https://doi.org/10.1088/1755-1315/679/1/012017

59 Cappuccino, J.G.; Sherman, N. Microbiology: A Laboratory Manual, 10th Edition, Rockland Community College, Inc, Publishing as Benjamin Cummings, San Fransisco, United States, 2014; pp 110-168. 